\title{
Credit Risk and Banking Stability: A Comparative Study between Islamic and Conventional Banks
}

Ferhi A*

Higher Institute of Management of Tunis, Tunisia

"Corresponding author: Ferhi Afifa, Ph.D, Higher Institute of Management of Tunis, 41, Avenue de la Liberté, Cité Bouchoucha, Le Bardo 2000 - Ave de la Liberte, Tunis 2000, Tunisia, Tel: +216 71588 514; E-mail: ferhi_afifa1983@yahoo.fr

Rec date: May 08, 2017, Acc date: Aug 01, 2017, Pub date: Aug 31, 2017

Copyright: (c) 2017 Ferhi A. This is an open-access article distributed under the terms of the Creative Commons Attribution License, which permits unrestricted use, distribution, and reproduction in any medium, provided the original author and source are credited.

\begin{abstract}
This aim of this research is to evaluate the credit risk of Islamic and conventional banks and its relationship with the capital in 14 countries of the MENA region. To do this, we used a sample of 58 Islamic banks and 89 conventional banks during the $2005-2015$ periods. In fact to measure the difference between Islamic banks and their conventional counterparts in terms of credit risk, the GMM is used. The results showed that the conventional model has a higher credit risk than the Islamic one. These results also showed that the larger an Islamic bank is, the higher its credit risk will be to get closer to that of conventional banks.
\end{abstract}

Keywords: Credit risk; Capital; Islamic banks; Conventional banks

\section{Introduction}

The recent financial crisis started in the sub-prime mortgage sector in the United States in the fall of 2008 to propagate and trigger a financial crash that shook the international stock markets, and led to the collapse of the pillars of the global finance and then to a recession that affected the entire planet. This crisis caused further damage and casualties throughout the world to the extent that it became one of the major financial crises in history, which raised the curiosity of many analysts and economists. It is in fact an opportunity to review the current foundations of the international financial system characterized by an excess of financialization which distinguishes the real from the financial economy and encourages indebtedness and speculative drifts, which weakens the system and exposes it to more crises in the future.

In Europe, an amount of 275 billion Euros at the marginal rate of 4.08\% was injected in August 2007 by the European Central Bank (ECB) in order to help banks avoid successive liquidity problems that investors were subject to and also to avoid the paralysis of the credit market. The amount of loans given by banks was remarkably reduced. This step was reached after a phase characterized by the increase of the degree of the loans offered along with the increase of the number of default debtors. Because of the subprime crisis, the eighth British bank, Northern Rock, a specialist in mortgages, fell into a situation of illiquidity. For this reason, the bank of England intervened to help it by playing the role of the lender of last resort (RDP).

The main source of the lack of liquidity within this institution is the mistrust of the second-tier banks that refused to lend liquidity, fear of its possible exposure to the subprime mortgage market. This "Subprime Credit" emphasized Islamic finance and presented it as a means of regulating the world economy, especially after the many weaknesses that finance has experienced. In this fragile macroeconomic context, the sentiment of the financial markets fluctuated according to the actions of the authorities.

With the enormous losses caused by the crisis, most of the world countries turned first to ethical and Islamic finance that unveiled its evidence during the subprime crisis [1,2]. In this regard, Tarik and Masmoudi [3] stressed that it is time to turn to Islamic finance. Islamic finance showed great resilience in time of crisis, and even a growth reaching $15 \%$. In addition, Islamic banks are more resilient than their conventional counterparts. A thorough literature has been developed by Siraj and Pillai [4]; Beck et al. [5]; Faye et al. [6]; Rajhi and Hassairi [7] over the last few decades on the feasibility and stability of the Islamic banking system.

Islamic finance, as an ethical finance, through its principles based on the interest rate that prohibit risk sharing as well as the backing of any financing to real assets, can help to promote the better risk management, both for the financial institutions and their clients. In the same context, a number of empirical studies, such as those by Pappas et al. [8], Abedifar et al. [9], Beck et al. [5], have undertaken a comparative analysis of the credit risk of Islamic and conventional banks. A part of this literature concluded that Islamic banks are more stable, while other parts found no differences in terms of credit risk and stability between the two banking sectors. According to the Bank for International Settlements (2000), credit risk is a major source of financial instability in the banking sector. The global financial crisis is only the most recent example where bad credit risk management had a disastrous effect on the economy. The Bank for International Settlements (2000) states that to have appropriate credit risk management systems in place, banks must identify measure, monitor and adequately control credit risk. The appropriate measure of credit risk provides foundations to develop prudential supervisory and control mechanisms to manage credit risk.

The ultimate goal of this study is to analyze the credit risk of the two banking sectors (Islamic and conventional) during the period 2005-2015. This period was characterized by the outbreak of the subprime crisis followed by the Euro zone sovereign crisis. Similarly, the objective of this study is to investigate the relationship between capital and credit risk using the Generalized Method of Moments (GMM).

We are making two main contributions. First, we complement a previous literature by comparing the credit risk of Islamic and 
conventional banks in 14 countries of the MENA region. We have chosen the regions where the Islamic banks operate alongside and in competition with their conventional counterparts.

Second, the study period includes the subprime crisis and that of the Euro zone, unlike other documents that examined the phenomenon during a single crisis.

The remainder of this article is structured as follows; Section 2 presents a review of the literature, while section 3 includes a description of the data and methodologies employed. The empirical results are discussed in section 4 and the final section provides the main concluding remarks and the potential implications of the research.

\section{Literature Review}

\section{Credit risk in the Islamic banking products}

The main cause of credit risk is that the debtors do not respect the deadlines of their commitments that exist in the terms of contract. In fact, credit risk exists when the counterparts are unable to perform and determine their obligations on the fixed date. The net income and the market value of the shares are still in a zone of uncertainty because of this type of risk.

Because of the principles of Sharia (Islamic law), according to which the Islamic banks operate, some Islamic financial products impose an additional credit risk on the banks; they practice $[10,11]$. Credit risk may occur in several types of Islamic banking contracts, such as the Salam contract, the Mourabaha, Musharaka, Mudaraba contracts.

The Mudarabah contract (profit sharing) is generally used in trade between the owner of the capital (Rab-al mal) and the contractor called (Moudarib). The capital is transformed into commodity in a first step. Subsequently, these goods will be resold to finally return to their liquid form. The gain, if it exists, is known and shared as agreed. Consequently, the credit risk takes the form of a counterparty risk due to the poor performance of the partner. This poor performance can be due to external causes due to systematic causes.

In the Musharakah contract (profit-and-loss), the banks and the other partners provide capital and share the profit and the loss on a predetermined ratio. Most scholars of Sharia agree that the Musharakah presents the Islamic banking product the closest to financing with interest. However, due to the information asymmetry, the bank is again exposed to a high level of the credit risk with the partner investor [10] as well as a significant risk of capital depreciation. The credit risk of this type of contract manifests itself when the contractor does not pay the part returning to the bank when this one becomes due.

The most popular Islamic financial product is the Murabahah contract, since it accounts for nearly $70-80 \%$ of all Islamic banking transactions. This is a sales contract where the buyer (borrower) provides the necessary information to the bank regarding his purchasing requirements. The bank then buys the product (asset) on behalf of a customer, then it resells it at a predetermined price in advance between the Islamic bank and the customer. Payment is made in several deadlines. redit risk arises when a party delivers goods before receiving the consideration for his financing and is therefore exposed to potential losses [12].
Concerning the Salam contract, it is a technique from which the payment is made in advance. On the date of the signature of the contract, the buyer must pay the corresponding sum in full to the seller but the products will be delivered later. Islamic banks face credit risk here if the products are not delivered at the fixed time [13].

Credit risks can be summarized according to the type of contract in the following Table 1 .

\begin{tabular}{|l|l|}
\hline Types of Contracts & Risks \\
\hline Salam contract & $\begin{array}{l}\text { This risk is attached to the non-payment occurring } \\
\text { when a party of the contract advances funds before } \\
\text { receiving the consideration for his financing and is } \\
\text { therefore exposed to losses [13]. }\end{array}$ \\
\hline Mourabaha Contract & $\begin{array}{l}\text { This risk is attached to the non-payment occurring } \\
\text { when a party of the contract issues a commodity } \\
\text { before receiving the consideration for his financing } \\
\text { and is therefore exposed to losses [14,15]. }\end{array}$ \\
\hline $\begin{array}{l}\text { Musharaka } \\
\text { Mudaraba contract }\end{array}$ & $\begin{array}{l}\text { Credit risk of this type of two contracts manifests } \\
\text { when the contractor fails to pay the share accruing to } \\
\text { the bank when it becomes due [10]. }\end{array}$ \\
\hline
\end{tabular}

Table 1: Risks by the type of contract.

\section{Empirical Studies}

A number of empirical studies have undertaken a comparative analysis of the credit risk of conventional and Islamic banks. As a result of preliminary work by Čihák and Hesse [16], several other studies 2011, Pappas et al., Abedifar et al. $[5,8,9,17]$ compared the relative stability of Islamic and conventional banks in different periods and between different countries. Part of this literature concluded that Islamic banks are more stable while others did not find any difference in terms of credit risk between the two banking systems. Obviously, there is always some variation in the results from the sample as well as the study period.

Boumediene [18] analyzed the level of credit risk in Islamic and conventional banks, particularly in nine conventional and Islamic banks over the period 2005-2009. The results of this study suggest that Islamic banks have a much lower credit risk than conventional banks.

In the same context, Beck et al. [5] compared the stability of conventional and Islamic banks. The results of the $\mathrm{Z}$ score ratio showed that Islamic banks have a much lower credit risk than conventional banks.

Later, and in the same context, Beck et al. [5] used the NPL ratio as an indicator of asset quality and found that the values of doubtful debts of Islamic banks are lower than those of their conventional counterparts, suggesting a lower credit risk in Islamic banks. In the same vein, Abedifar et al. [9] compared the credit and insolvency risk of 553 banks in 24 countries between 1999 and 2009 using three different accounting ratios to measure credit risk and several forms of $\mathrm{Z}$ to measure the risk of insolvency. They found that Islamic banks are more stable and less risky than conventional banks.

Other studies in this field found results different from those achieved by Boumediene [18], Beck et al. [5] and Abedifar et al. [9], such as the study of Gamaginta and Rokhim [17] and Fayed [19].

Gamaginta and Rokhim [17] compared the credit risk of 12 Islamic banks to 72 conventional banks in Indonesia and found that Islamic 
Page 3 of 7

banks are generally less stable. In addition, small Islamic banks proved to have the same level of stability as the conventional small banks.

Indeed, Fayed [19] showed the superiority of conventional banks in terms of liquidity, credit risk management, solvency and profitability. Similarly, Miah and Sharmeen [20] showed that the conventional banks are more efficient in managing costs than Islamic banks.

Other researchers, such as Jawadi et al. [21] showed that there is no significant difference between Islamic and conventional banks in terms of financial risk.

\section{Data and Model Specifications}

\section{The data}

Our investigation is based on actual data for each bank available in the Bank-Scope database provided by the Van Dijik office. It should be noted that almost all the recent empirical studies interested in the world banking sector essentially use this database.

We use data relative to 147 banks (58 Islamic banks and 89 Conventional banks), 1617 observations for 11 years (2005-2015). This period is chosen because it contains the last two financial crises, such as the subprime and the Euro zone crises. The countries available in this part are 14 countries of the MENA region, such as Saudi Arabia, Bahrain, Egypt, Iran, Jordan, Kuwait, United Arab Emirates, Yemen, Qatar, Tunisia, Turkey, Lebanon, Mauritania, and Sudan.

\section{Model specifications}

In this section, we present the three empirical models used to analyze the risks and the fragility of the banking system as well as the relationship or linkage between banking credit risk and capitalization in a comparative study between the two models of the two banking sectors (Islamic and classical).

Following the same vein as Altunbas et al. [22], we see that the first two equations are as follows:

$$
\begin{aligned}
& \text { CRisk }_{i, t}=\alpha_{0}+\alpha_{1} \text { CRisk }_{i, t-1}+\alpha_{2} \text { Size }_{i, t}+\alpha_{3} \text { ETA }_{i, t}+ \\
& \alpha_{4} \text { Ineff }_{i, t}+\alpha_{5} \text { HHI }_{i, t}+\alpha_{6} \operatorname{CGDP}_{i, t}+\alpha_{7} \text { ROAA }_{i, t}+ \\
& \sum_{t=1}^{7} \alpha_{8, t} \text { Choc }_{i, t}+\varepsilon_{1, i, t} \\
& \text { ETA }_{i, t}=\beta_{0}+\beta_{1} \text { ETA }_{i, t-1}+\beta_{2} \operatorname{Size}_{i, t}+\beta_{3} \text { CRisk }_{i, t}+ \\
& \beta_{4} \text { Ineff }_{i, t}+\alpha_{5} \text { HHI }_{i, t}+\alpha_{6} \text { CGDP }_{i, t}+\alpha_{7} \text { ROAA }_{i, t}+ \\
& \sum_{t=1}^{7} \alpha_{8, t} \text { Choc }_{i, t}+\varepsilon_{1, i, t}
\end{aligned}
$$

Where the index "i" denotes the banks and "T" denotes the temporal dimension. Credit risk (Risk) and equity (ETA) are modeled respectively in the equations of 1 to 3 .

\section{The Results of the Empirical Analysis}

\section{Result of the descriptive analysis}

Table 2 below illustrates the descriptive statistics for the variables

\begin{tabular}{|c|c|c|c|c|c|}
\hline & & \multicolumn{2}{|c|}{ Islamic banks } & \multicolumn{2}{|c|}{ Conventional Banks } \\
\hline & & Mean & SD & Mean & SD \\
\hline & $\begin{array}{l}\text { ETA } \\
\text { (Capitalization) }\end{array}$ & 2.072064 & 1.781732 & 2.743271 & 7.813891 \\
\hline & Size & 3.521797 & 0.829398 & 3.691994 & 0.645667 \\
\hline \multirow[t]{4}{*}{$\begin{array}{l}\text { General } \\
\text { descriptive } \\
\text { statistics }\end{array}$} & $\begin{array}{l}\text { ROAA (the } \\
\text { ratio of net } \\
\text { income to total } \\
\text { assets) }\end{array}$ & 3.44287 & 5.602425 & 2.65471 & 5.02115 \\
\hline & $\begin{array}{l}\text { CGDP (The } \\
\text { growth rate of } \\
\text { GDP) }\end{array}$ & 0.03294 & 0.16014 & 0.0318763 & 0.0798133 \\
\hline & $\begin{array}{l}\text { INEF } \\
\text { (inefficiency) }\end{array}$ & 0.254735 & 0.261815 & 0.3563555 & 0.452371 \\
\hline & $\begin{array}{l}\text { LLRGL (loan- } \\
\text { loss reserves } \\
\text { to gross loans) }\end{array}$ & 12.79231 & 51.28152 & 17.3928 & 7.81389 \\
\hline $\begin{array}{l}\text { Credit risk } \\
\text { measurement }\end{array}$ & $\begin{array}{l}\text { LLPAGL(loan- } \\
\text { loss provisions } \\
\text { to average } \\
\text { gross loans) }\end{array}$ & 4.88175 & 21.01197 & 10.77693 & 36.39621 \\
\hline
\end{tabular}
used in our empirical investigation. We note that, on average, the value of the "ROAA" in Islamic banking is higher than that of conventional banks with a margin of "0.79". As a measure of the bank's ability to create profit, it can be emphasized that the Islamic banks in our study sample are more capable of generating profits.

Table 2: General descriptive statistics.

Likewise, we can highlight, according to the results, that the average credit risk (measured according to the two ratios "LLPAGL" and "LLRGL") is higher in the conventional banks than in their Islamic counterparts. This result is consistent with the reality that Islamic banks do not grant mortgage loans which is the main reason of the subprime crisis. The Shariah prohibits interest, encourages the banks to grant loans backed by tangible assets, and prohibits securitization, which protects Islamic banks against defaulting loans.

With an average value of "INFF" equal to 0.254 in Islamic banks and 0.356 in conventional banks, one can deduce that Islamic banks are perhaps more efficient than their conventional counterparts [23]. 'Based on the average values of the' market share 'variable, it is found that it illustrates a difference between the two samples in favor of the conventional context.

Similarly, on the basis of the results obtained in the table above, it can be seen that the average values of the two variables 'ETA' and 'size' are higher in conventional banks than in their Islamic counterparts.

\section{Results using the generalized moments method (GMM)}

We use the GMM technique in two steps. In the first one, we will estimate the two simultaneous equations of credit risk (LLPAGL) and capital (ETA), and in the second, we will analyze the credit risk (LLRGL) and the capital (ETA).

By referring to referring to the results shown in the Table 3 above, we note that the "shock" variable has a positive and statistically significant impact on credit risk (LLRGL) within both Islamic and conventional banks. Thus, it can be stressed that during the period of 
the financial crisis, the credit risk of Islamic and traditional banks increases. The values of the coefficients $(\beta)$ of the two financial sectors show that the credit risk in the conventional banks is higher than that of their Islamic counterparts. According to the Bank for International Settlements (2000), credit risk is one of the main sources of financial instability in the banking sector. The international financial crisis (subprime crisis) has shown that poor credit risk management has had a catastrophic effect on the global economy. This result confirms the result deduced from the research of Boumediene [18].

\begin{tabular}{|c|c|c|c|c|}
\hline \multirow[b]{2}{*}{ Variables } & \multicolumn{2}{|c|}{ Banques conventionnelles } & \multicolumn{2}{|c|}{ Banques islamiques } \\
\hline & LLRGL (1) & ETA (2) & LLRGL (3) & ETA (4) \\
\hline Constant & -2.7156 & -0.52011 & -0.2547 & -0.57703 \\
\hline Size & $0.0814^{\star \star}$ & $0.1694^{*}$ & $.07447^{* *}$ & $.1817^{\star \star *}$ \\
\hline CGDP & 0.0049 & 0.0182 & -0.00266 & 0.00811 \\
\hline $\mathrm{HHI}$ & $0.2148^{*}$ & $0.08415^{*}$ & $.0044^{*}$ & 0.13511 \\
\hline Choc & $1.014^{\star *}$ & $-0.0644^{* *}$ & $.5171^{\star *}$ & $-.0577^{\star \star \star}$ \\
\hline ETA & $-0.54571^{*}$ & & $-.7441^{*}$ & \\
\hline Inefficiency & 0.711 & $-0.0632^{\star *}$ & 0.4521 & $-.0541^{*}$ \\
\hline ROAA & 0.0721 & $0.2241^{*}$ & 0.061352 & $.2188^{*}$ \\
\hline
\end{tabular}

Notes ${ }^{*},{ }^{* *}$ and ${ }^{* * *}$ indicate significance at $1 \%, 5 \%$, and $10 \%$ respectively.

Table 3: Results of simultaneous equation estimates of credit risk (LLRGL) and capitalization (ETA).

The negative impact of the "shock" capital (ETA) variable within the Islamic and conventional banks shows that, during the crisis period, the solidity of the two usurious and Islamic financial sectors is decreasing. Based on the values of the coefficients $(\beta)$, we find that the Islamic banks are more solid and more stable than their conventional counterparts with a margin of 0.19 .

Based on the results of estimates (1), (3), we observe that the capitalization (ETA) has a negative and statistically significant impact on the credit risk (LLRGL) of Islamic and conventional banks. The magnitude of 0.54 indicates that a $1 \%$ increase in capitalization (ETA) decreases the credit risk of the conventional banks by about $0.5 \%$. However, the magnitude of 0.74 means that an increase by $1 \%$ of capitalization decreases the credit risk of Islamic banks by about $0.7 \%$. Returning to the values of the coefficients $(\beta)$ of Islamic and conventional banks, we noted that the negative effect of capital (ETA) on credit risk (LLRGL) remains higher in the Islamic financial sector.

On examining the reverse direction, that is to say, the effect of credit risk (LLRGL) on capital (ETA), we can observe from the results of the second equation that the extent of 0.033 indicates that a $1 \%$ increase in credit risk (LLRGL) of conventional banks decreases (ETA) by about $0.03 \%$. Concerning the Islamic banks and the results of equation (4), we observe that the credit risk (LLRGL) has a negative and statistically significant effect on capital (ETA). The magnitude of 0.018 indicates that a $1 \%$ increase in credit risk reduces capital by approximately $0.01 \%$. By comparing the values of the coefficients $(\beta)$ of the Islamic and conventional banks, it can be pointed out that the negative relationship between credit risk (LLRGL) and capital (ETA) remains higher in conventional banks.
The results of estimating the relationship between the "LLRGL" and the "size" variable show that there is a positive correlation between the two variables during the period considered and for the whole sample studied. As a result, it can be emphasized that when the size of a bank increases, the credit risks (LLRGL) increases. From these results, it appears that the positive impact of the size on credit risk is lower for Islamic banks compared to conventional banks, but with a margin that does not exceed "0.06\%". The increase of banking risk in the large Islamic banks is due to the limitation of risk management tools. In addition, the problem of assessing governance is due to the risk of information asymmetry and moral hazard. The use of Al Musharaka, as a financing instrument in a massive way in large Islamic banks as compared to small one, involves high-risk investment assets.

In addition, the results in equation (1) indicate that the growth of the Herfindhal Hirschman Index (HHI) of conventional banks causes significant changes in credit risk (LLRGL) at $1 \%$ threshold. The magnitude of 0.21 implies that a $1 \%$ increase of the HHI increases the credit risk (LLRGL) of conventional banks by around $0.2 \%$. Therefore, with reference to this finding and the results in equation (3) of Islamic banks, it can be pointed out that the credit risk in conventional banks is more affected by the concentration of markets than the Islamic counterparts. This result is consistent with the findings of Pejman, Philip, Amine.

Similarly, the results mentioned in the table above show that an increase of the "ROAA" variable by $5 \%$ leads to a capital increase of the conventional banks by about $0.22 \%$, while a magnitude of 0.21 implies that a $1 \%$ increases of "ROAA" increases the capital of the Islamic banks by about $0.21 \%$.

\begin{tabular}{|c|c|c|c|c|}
\hline & \multicolumn{2}{|c|}{ Conventional banks } & \multicolumn{2}{|c|}{ Islamic banks } \\
\hline & LLPAGL (1) & ETA (2) & LLPAGL (3) & ETA (4) \\
\hline Constant & -0.4587451 & -0.21547451 & 0.1386541 & -0.487542 \\
\hline Size & $.0354175^{*}$ & $0.164522^{* *}$ & $0.027412^{*}$ & $0.184852^{* * *}$ \\
\hline CGDP & -0.365247 & 0.017542 & -0.0652417 & 0.017843 \\
\hline $\mathrm{HHI}$ & $0.0142517^{* *}$ & $0.5878643^{*}$ & $0.005264^{\star * *}$ & 0.1138849 \\
\hline ETA & $-0.765245^{*}$ & & $-0.832985^{\star \star *}$ & \\
\hline Inefficiency & 0.295428 & -1.04754 & 0.1185647 & $-0.0746982^{* *}$ \\
\hline Choc & $0.4025721^{* *}$ & $-0.0642538^{* *}$ & $0.065244^{\star *}$ & $-.0569425^{\star *}$ \\
\hline ROAA & 0.076958 & $0.2369854^{\star *}$ & 0.0336254 & $0.213542^{* * *}$ \\
\hline LLPAGL & & $-0.065241^{* *}$ & & $-0.0375124^{*}$ \\
\hline
\end{tabular}

Table 4: Results of estimates of simultaneous equations of both credit risk (LLPAGL) and of capital (ETA).

Table 4 above illustrates the relationship between the two simultaneous equations, namely, the "LLPLGL" credit risk and the "ETA" capitalization.

Based on the value of the "shock" variable in the first and third equations $(1,3)$, we note that this variable has a positive and significant effect on the "LLPAGL" credit risk. It should be noted, therefore, that during the period 2007-2012, the "LLPAGL" credit risk of conventional and Islamic banks increases compared to the study period 2005-2015. 
Page 5 of 7

The comparison of the values of the coefficients $(\beta)$ of the "shock" variable of the Islamic banks and their conventional counterparts revealed that the "LLPAGL" credit risk proxy increases more heavily in conventional banks than in the Islamic Banks with a margin of 0.3.

From the same table, we can deduce that the "shock" variable has a significant and negative effect on the "ETA" capital of Islamic and conventional banks. By comparing the two banking sectors, we can be seen that, during the period 2007-2012, the capital of conventional banks decreases more than that of their Islamic counterparts with a margin of $0.8 \%$.

From the results obtained by the two equations (1) and (3), we note that the "ETA" capitalization has a negative and statistically significant effect on the "LLPAGL" credit risk The magnitude of 0.76 indicates that a $1 \%$ increase of the ETA reduces the "LLPAGL" credit risk of conventional banks by about $0.76 \%$, while a magnitude of 0.83 indicates that a $10 \%$ increase of capitalization reduces credit risk by $0.83 \%$. By comparing the two banking systems (Islamic and conventional), we find that the negative impact of "ETA" capitalization on "LLPAGL" credit risk affects the Islamic banks in a way slightly higher than that it does with the conventional banks.

By studying the opposite direction, that is the impact of credit risk (LLPAGL) on capital, and according to the results obtained in the second equation, we can emphasize that an increase of "LLPAGL" credit risk by $5 \%$, decreases the capital of conventional banks by about 0.065 . However, an increase of credit risk by around $1 \%$, decreases the capital of Islamic banks by about 0.037 . Based on the values of the coefficients $(\beta)$, we note that the negative effect of "LLPAGL" credit risk" on (ETA) capitalization remains higher in conventional banks than in their Islamic counterparts.

The relationship between the "size" variable and the "LLPAGL" credit risk remains significant and positive. A magnitude of 0.035 implies that a $1 \%$ increase of the size of conventional banks increases credit risk in the order of $0.03 \%$, while the magnitude of 0.027 indicates that a $1 \%$ increase of the size of Islamic banks increases the "LLPAGL" credit risk by about $0.027 \%$. Thus, the positive relationship between the "size" variable and credit risk (LLPAGL) seems a little higher in conventional banks than in the Islamic ones. Therefore, it can be concluded that, the larger the size of Islamic banks, the higher credit risk until it becomes very close to that of conventional banks.

The same table analyzed above also indicates that the "size" variable has a significant and positive effect on the "ETA" capitalization. According to the two values of the coefficients $(\beta)$ of the Islamic banks and their classical counterparts $\left(0.16^{* *}, 0.18^{* * *}\right)$, we deduce that the positive impact of size on the "ETA" ratio is higher in Islamic banks than in their conventional counterparts.

\begin{tabular}{|c|c|}
\hline Variables & Definition \\
\hline Credit risk & $\begin{array}{l}\text { We use three proxies for credit risk (Loan Risk): the ratio of loan-loss reserves to gross loans (LLRGL) and the ratio of loan-loss } \\
\text { provisions to average gross loans (LLPAGL). These proxies are similar to the variables used by Cebenoyan and Strahan and } \\
\text { Altunbas et al. [22]. }\end{array}$ \\
\hline Capitalization (ETA) & $\begin{array}{l}\text { The ratio of capital to total assets indicates the adequacy of capital that captures the overall security and soundness of the financial } \\
\text { institution. It shows a bank's ability to absorb unexpected losses. }\end{array}$ \\
\hline Inefficiency & 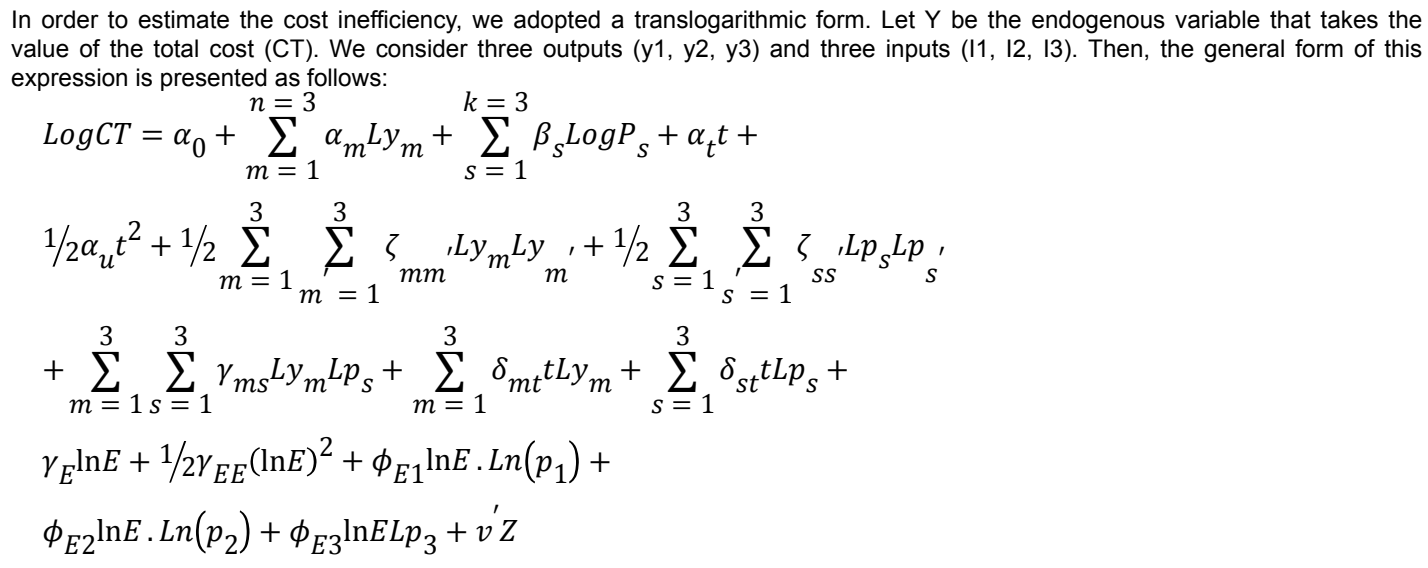 \\
\hline Size & The size of the firm is measured by the logarithm of total assets, Aloy (2014). \\
\hline ROAA & $\begin{array}{l}\text { ROAA is the ratio of net income to total assets. It therefore indicates the ability of the bank to generate profit from its asset base. } \\
\text { The greater this ratio, the more efficient the bank and the more profits it can generate. Although this ratio is not weak, since it does } \\
\text { not take into account the so-called off-balance sheet assets, it is the most widely used performance indicator. }\end{array}$ \\
\hline The growth rate of GDP (CGDP) & $\begin{array}{l}\text { The GDP growth measures the overall health of the economy, which in turn may reflect the level of credit demand. Thus, an } \\
\text { increase of GDP growth can lead to a credit increase. Economic growth is therefore positively correlated with the demand for } \\
\text { credit. Indeed, Dell'Ariccia et al. (2012) explain that, in a period of expansion, a good level of economic growth improves the } \\
\text { solvency of borrowers. } \\
\text { Lenders then respond with an increase of supply and easing of credit conditions. An increase of credit will thus increase investment } \\
\text { and consumption. }\end{array}$ \\
\hline
\end{tabular}




\begin{tabular}{|c|c|c|}
\hline $\begin{array}{l}\text { Hirschman-Herfindahl } \\
(\mathrm{HHI})\end{array}$ & index & $\begin{array}{l}\text { The Hirfendahl-Hirschman Index (HHI) is commonly used. In the USA, the } \mathrm{HHI} \text { plays an important role in the antitrust enforcement } \\
\text { process in the banking sector. It is called the complete index-information, as it captures the characteristics of the whole distribution } \\
\text { of the size of the banks. For } \mathrm{n} \text { companies in an industry with market shares } \mathrm{S}_{\mathrm{i}},(\mathrm{i}=1,2, \ldots, \mathrm{n}) \text {, The HHI Is defined as follows: } \\
H H I=\sum_{i=1}^{n} s_{i}^{2}\end{array}$ \\
\hline Variable shock & & We define $c h o c=0$ during the period $2003-2006$ and $c h o c=0$ for the period $2007-2012$. \\
\hline
\end{tabular}

Table 5: Definition of the variables.

Table 5 above also shows that the "HHI" variable indicating that the growth of the Herfindhal Hirschman Index has a significant and positive effect on the "LLPAGL" credit risk proxy and the "ETA" capitalization. Returning to the values of the coefficients $(\beta)$ of both the Islamic and classical sectors, it can be pointed out that the $\mathrm{HHI}$ variable influences the "LLPAGL" credit risk and the "ETA" capitalization of conventional banks more significantly than in the BI. This result is consistent with the findings of Naceur and De Jonghe.

\section{Conclusion}

The objective of this paper was to examine whether Islamic banks face higher credit risk than their conventional counterparts. We used two measures for credit risk: the ratio of loan-loss reserves to gross loans (LLRGL) and the ratio of loan-loss provisions to average gross loans (LLPAGL). At the same time, we examined the relationship between credit risk and capital using the Generalized Method of Moments (GMM) in 14 MENA countries over the period 2005-2015. The findings suggest that conventional banks have a higher credit risk than their Islamic counterparts. This credit risk has a high effect on the exposure of financial crises because it is capable of putting the bank in distress if it is not properly managed.

However, we have observed in parallel that, the larger the size of Islamic banks is, the higher credit risk to the extent to become very close to that of conventional banks. The increase of credit risk in the largest Islamic banks can be explained by the fact that the latter, in the course of their activities and operations, do not differ from their conventional counterparts. They transfer the conventional funding framework to a context that respects Islamic law. Their role thus remains a financial intermediation which, by sharing profits and losses with their customers, gradually deteriorates in favor of a simple intermediation. This conclusion is also proven by the difference in the risk of the debt linked mainly with the financing and insolvency operations which emerged from participation activities.

This investigation therefore advocates that Islamic banks face crises because of the dominance of the type of financing by debt in relation to participatory techniques.

The analysis of the links between the two variables "credit risk" and "capitalization" leads us to conclude that an increase of credit risk leads to a decline of the capital of the two banking sectors (Islamic and conventional banks). This negative effect of credit risk on capital remains higher in conventional banks than in their Islamic counterparts.
The current crisis offered Islamic banks the opportunity to demonstrate their ability to resist, but also revealed serious challenges that these banks must meet in order to sustain their growth.

The strong dominance of debt financing operations in relation to participatory operations makes the financing context, according to the Islamic principles, closer to the classical context because the IB, with the modes of debt and quasi-Debt, is merely an intermediary between the claimants and the sellers of the goods.

The increase of banking risk in the large Islamic banks is due to the limitation of risk management tools. In addition, the problem of governance and its evaluation is due to the risk of information asymmetry and moral hazard.

\section{References}

1. Siddiqui A (2008) "Financial contracts, risk and performance of Islamic banking". Managerial Finance 34: 680-694.

2. Hasan M, Dridi J (2010) "The Effects of the Global Crisis on Islamic and Conventional Banks: A Comparative Study", IMF Working Paper 201: $1-46$.

3. Massmoudi, Tarik B (2010) "La Finance Islamique dans le contexte de la crise financière: opportunités et defies". Fiance. Note pour Capmena mars 2010.

4. Siraj KK, Pillai PS (2012) "Comparative study on performance of Islamic banks and conventional banks in GCC region". Journal of Applied Finance and Banking 2: 123-161.

5. Beck T, Demirgüç-Kunt A, Merrouche O (2013) "Islamic vs. conventional banking: Business model, efficiency and stability". Journal of Banking and Finance 37: 433-447.

6. Faye I, Triki T, Kangoye T (2013) “The Islamic finance promises: evidence from Africa". Review of Development Finance 3: 136-151.

7. Rajhi W, Hassairi SA (2014) "Islamic banks and financial stability: a comparative empirical analysis between MENA and southeast Asian countries". Productivité et capital humain dans les pays du Sud de la Méditerranée: Région et Développement 37: 149-177.

8. Pappas V, Izzeldin M, Fuertes AM, Ongena S (2012) "A Survival Analysis of Islamic Bank Failure Risk". Journal of Financial Services Research 51: 221-256.

9. Abedifar P, Molyneux P, Tarazi A (2013) "Risk in Islamic banking". Eur Finan Rev 17: 2035-2096.

10. Sundararajan V, Errico L (2002) "Islamic financial institutions and products in the global financial system: Key issues in risk management and challenges ahead". International Monetary Fund pp: 1-28.

11. Kabir MN, Worthington AC (2014) "Credit risk in Islamic financial products". In: Worthington AC. (Ed.) Contemporary Issues in Islamic Finance: Principles, Progress, and Prospects. Nova Publishing, New York, pp: 73-84. 
Citation: Ferhi A (2017) Credit Risk and Banking Stability: A Comparative Study between Islamic and Conventional Banks. Intel Prop Rights 5: 193. doi:10.4172/2375-4516.1000193

Page 7 of 7

12. Haron A, Hock JLH (2007) "Inherent risk: credit and market risks. Islamic Finance". John Wiley and Sons (Asia) Pte Ltd. pp: 94-120.

13. Rahman AA, Shahimi S (2010) "Credit risk and financing structure of Malaysian Islamic banks". Journal of Economic Cooperation and Development 31: 83-105.

14. Ahmed A (2010) "Islamic Banking: How to manage risk and improve profitability". John Wiley and Sons.

15. Iqbal Z, Mirakhor A (2011) "An introduction to Islamic finance: Theory and practice". John Wiley \& Sons.

16. Čihák M, Hesse H (2010) "Islamic banks and financial stability: an empirical analysis". J Financ Serv Res 38, 95-113.

17. Gamaginta, Rokhim R (2011) "The stability comparison between Islamic banks and conventional banks: evidence in Indonesia". 8th International Conference on Islamic Economics and Finance, Doha, Qatar.

18. Boumediene A (2011) "Is credit risk really higher in Islamic banks?" J Credit Risk 7: 97-129.
19. Fayed ME (2013) "Comparative performance study of conventional and Islamic banking in Egypt". Journal of Applied Finance and Banking 3: $1-14$.

20. Miah MD, Sharmeen K (2015) "Relationship between capital, risk and efficiency: A comparative study between Islamic and conventional banks of Bangladesh". International Journal of Islamic and Middle Eastern Finance and Management 8: 203-221.

21. Jawadi F, Chaffou AI, Jawadi N (2016) "Do Islamic and conventional banks really differ? A panel data statistical analysis". Open Economies Review 27: 293-302.

22. Altunbas Y, Carbo S, Gardener EPM, Molyneux P (2007) "Examining the relationships between capital, risk and efficiency in European banking". European Financial Management 13: 49-70.

23. Abdull-Majid M, Saal DS, Battisti G (2010) "Efficiency in Islamic and conventional banking: an international comparison". J Prod.Anal 34: $25-43$. 